\title{
DETECÇÃO DE ANTICORPOS ANTI-Rhodococcus equi EM ÉGUAS VACINADAS E POTROS PELO ENSAIO IMUNOENZIMÁTICO INDIRETO
}

\author{
Carla Braga Martins, ${ }^{1}$ Marco Augusto Giannoccaro da Silva, ${ }^{2}$ Claudia Acosta Duarte, ${ }^{3}$ \\ Raquel Mincarelli Albernaz, ${ }^{4}$ José Correa de Lacerda Neto ${ }^{5}$ e Rosangela Zacarias Machado ${ }^{6}$ \\ 1. Professora adjunto da Universidade Federal do Espírito Santo, Campus de Alegre. \\ E-mail: carlabraga74@hotmail.com \\ 2. Professor adjunto da Universidade Federal do Tocantins, Campus de Araguaína \\ 3. Professora adjunto da Universidade Federal do Pampa, Campus Uruguaiana \\ 4. Doutoranda da Faculdade de Ciências Agrárias e Veterinárias, UNESP, Campus de Jaboticabal, SP \\ 5. Livre-docente e professor adjunto de Clínica Médica de Equinos FCAV/UNESP, Campus de Jaboticabal \\ 6. Professora titular do Departamento de Patologia Veterinária da FCAV/UNESP, Campus de Jaboticabal.
}

\section{RESUMO}

Comparou-se a resposta imune humoral em éguas da raça Brasileiro de Hipismo (BH) e Bretão, após a imunização com a vacina anti-Rhodococcus equi, bem como avaliou-se o efeito da imunoprofilaxia ativa materna na transferência de anticorpos pelo colostro em equinos recém-nascidos. Coletaram-se amostras sanguíneas de dezesseis éguas prenhes vacinadas contra $R$. equi, dezesseis potros filhos das éguas vacinadas, oito éguas prenhes não vacinadas e oito potros filhos das éguas não vacinadas. Determinouse a titulação de anticorpos anti- $R$. equi utilizando-se o ensaio imunoenzimático indireto (ELISA) com os dois diferentes antígenos, APTX e antígeno da vacina comercial. Não houve diferença quanto à produção de anticorpos entre as duas raças. Observou-se aumento significativo na titulação de anticorpos anti- $R$. equi nas éguas após a vacinação $(\mathrm{p}<0,01)$ sem variação com a raça, com pico no momento do parto, seguido de diminuição até sessenta dias após o parto, permanecendo constante até 150 dias do pósparto. Houve transferência significativa de anticorpos $(p<0,01)$ via colostro para os potros recém-nascidos das éguas vacinadas, nos quais detectou-se diminuição dos títulos aos sessenta dias após o nascimento, a qual se manteve constante até 150 dias. O antígeno comercial detectou títulos de anticorpos significativamente maiores do que o antígeno APTX $(\mathrm{p}<0,01)$.

PALAVRAS-CHAVES: Anticorpos, ELISA, Rhodococcus equi, imunização, potros.

\section{ABSTRACT}

\section{ANTIBODIES DETECTION TO RHODOCOCCUS EQUI IN VACCINATED MARES AND FOALS BY INDIRECT ENZYME IMMUNOASSAY}

The humoral immune response in 'Brasileiro de Hipismo' (BH) breed and Breton mares was compared after using the Rhodococcus equi vaccine, and the effect of maternal immunoprophylaxis on antibody transfer to newborn foals through the colostrum was evaluated. Blood samples were obtained from 16 pregnant mares vaccinated against $R$. equi, 16 foals (offspring from vaccinated mares), 8 unvaccinated pregnant mares and 8 foals (offspring from control mares). $R$ equi serum antibody titers were determined by enzyme-linked immunosorbant assay (ELISA) after the immunization of pregnant mares using two different antigens, APTX and the commercial vaccine. There was no difference in antibody production between the two breeds. Significant increase in $R$. equi antibody titers was observed in mares after vaccination $(\mathrm{p}<0.01)$, reaching a peak at foaling. Afterward, titers tended to decrease for up to 60 days after birth (dab) and then remained constant until 150 dab. Significant antibody transfer to the vaccinated mares newborn foal occurred through the colostrum. A slight reduction in antibody titer was observed at $60 \mathrm{dab}$, after which titers remained constant for up to $150 \mathrm{dab}$. The commercial antigen detected significantly higher antibody titers than did APTX $(\mathrm{p}<0.01)$.

KEY WORDS: Antibodies, ELISA, Rhodococcus equi, immunization, foals. 


\section{INTRODUÇÃO}

O Rhodococcus equi (R. equi) é um constituinte natural da flora microbiana intestinal dos equinos e, em condições especiais, torna-se responsável pelo desenvolvimento de pneumonia abscedante e/ou enterite em potros nos primeiros seis meses de vida. A infecção é considerada oportunista em potros, ocorrendo no período no qual a imunidade conferida pelo colostro está diminuída e o sistema imunológico do recém-nascido ainda não está totalmente maduro. A importância dessa afecção reside, principalmente, no elevado prejuízo econômico acarretado pela perda de animais, em virtude da alta taxa de mortalidade do custo, duração e pouca eficiência do tratamento (TAKAI et al., 1986; PRESCOTT et al., 1997; BECÚ, 1999).

Algumas soluções têm sido tentadas por pesquisadores para prevenir possíveis falhas na transmissão passiva de imunoglobulinas e também no sentido de estimular a imunidade passiva e/ou ativa contra o $R$. equi. Concomitantemente, criadores de equinos e veterinários têm utilizado recursos como mudanças nas práticas de manejo e adequações sanitárias de pastos e instalações na tentativa de encontrar soluções práticas para o controle da rodococose equina.

A vacinação de éguas no final da gestação tornou-se uma prática corriqueira nos grandes haras. Embora a vacinação contra $R$. equi não seja feita de forma sistemática no Brasil, um número considerável de propriedades utiliza uma vacina produzida na Argentina, denominada, comercialmente, Rhodovac. ${ }^{1}$

Considerando-se a importância da doença e a falta de comprovação da eficiência da vacinação, este trabalho se propôs a avaliar a cinética da resposta de anticorpos (classe $\mathrm{IgG}$ ) anti-R. equi em éguas das raças Brasileiro de Hipismo (BH) e Bretão, prenhes, comparando o efeito da raça na produção e transferência de anticorpos para os neonatos.

\section{MATERIAL E MÉTODOS}

Utilizaram-se 24 éguas no último terço da gestação, com idade média de 10,37 $\pm 2,30$ anos, das quais dezesseis (oito da raça $\mathrm{BH}$ e oito Bretãs) pertenciam à da Fazenda São Geraldo, localizada no município de Ipuã, São Paulo. As demais oito éguas (mestiças de BH e Bretão) pertenciam ao Haras Pólo Regional de Desenvolvimento Tecnológico de Agronegócios da Alta Mogiana, situado em Colina, São Paulo, sendo deslocadas na Fazenda São Geraldo no terço final da gestação e permanecendo em piquetes de Coast-Cross, com água e sal mineral à vontade. Distribuíram-se esses animais em três grupos: o grupo I constituído por oito éguas da raça $\mathrm{BH}$; o grupo II, formado por oito éguas Bretãs (receptoras de embrião), ambas vacinadas contra $R$. que; o grupo III, formado por oito fêmeas mestiças de BH e Bretão não vacinadas (controle).

Também foram utilizados todos os conceptos $(\mathrm{n}=24)$ dos grupos I, II e III, potros $\mathrm{BH}$ provenientes ou não de transferência de embrião, com idade entre o momento do nascimento até os cinco meses de idade. Dividiram-se os potros em três grupos (IV, V e VI), formados, cada um, por oito animais. Os grupos IV e $\mathrm{V}$ foram formados pelos filhos das éguas vacinadas e o grupo VI pelos produtos das éguas não vacinadas, constituindo o grupo dos potros-controle.

As éguas dos grupos I e II receberam duas aplicações da vacina Rhodovac ${ }^{\circledR 1}$, que contém antígenos associados ao plasmídeo de $85-90 \mathrm{~kb}$ de virulência (VapA), exoenzimas, antígenos capsulares, somáticos e ácido micólico inativados com formol e precipitados em hidróxido de alumínio, ( $1 \mathrm{~mL} /$ dose $)$, por via subcutânea. A primeira dose foi administrada 45 dias e a segunda 15 dias antes da data prevista para o parto.

As éguas pertencentes ao grupo III não foram vacinadas, mas receberam administração de $1 \mathrm{~mL}$ de solução fisiológica por via subcutânea nos mesmos tempos referidos para vacina. Os potros pertencentes aos grupos IV, V e VI não receberam vacinação.

Os potros foram avaliados desde o nascimento até completar cinco meses de idade. O exame clínico consistiu em avaliação da aparência geral, presença de secreção nasal, temperatura retal e auscultação pulmonar.

As amostras de sangue $(10 \mathrm{~mL})$ das éguas foram colhidas por venopunção jugular, momentos antes das vacinações, ou seja, 45 e 15 dias antes da data prevista do parto, imediatamente após o parto, 60 e 150 dias após. Colheu-se o mesmo volume de sangue da veia jugular dos potros, antes da ingestão do colostro, assim como 24 e 48 horas após o nascimento, e aos 60 e 150 dias de idade. Após a separação do soro, $2 \mathrm{~mL}$ de cada amostra foram separadas em duas alíquotas de $1 \mathrm{~mL}$ e 
acondicionadas em microtubos, conservados a $-20^{\circ} \mathrm{C}$ até a ocasião das análises laboratoriais.

Testaram-se concomitantemente as amostras de soro com dois tipos de antígenos: o comercial - antígenos somáticos, exoenzimas e proteínas de virulência associadas ao plasmídeo de $85-90 \mathrm{~kb}-\mathrm{e}$ o APTX, que consiste em preparação semipurificada da proteína VapA, extraído pelo detergente Triton $\mathrm{X}$ e precipitado em acetona segundo o protocolo de PRESCOTT et al. (1997). O APTX foi produzido no laboratório de Parasitologia da Faculdade de Ciências Agrárias e Veterinárias da Universidade Estadual Paulista, UNESP, Jaboticabal/SP e submetido à eletroforese em gel de poliacrilamida (SDS-PAGE). Em seguida, transferiu-se o material para a membrana de nitrocelulose ${ }^{2}$ para o "Immunobloting", e incubação com o anticorpo monoclonal anti-VapA cedido pelo Instituto Adolfo Lutz, São Paulo, SP. Dessa forma, foi possível verificar a expressão da VapA em uma banda difusa com massa molecular de $15-17 \mathrm{kDa}$.

Procedeu-se à quantificação proteica do antígeno APTX por meio da análise de aminoácidos pelo método do fenil-tio-carbamil (PTC), utilizando-se a cromatografia líquida de alta pressão (HPLC). Já o conteúdo proteico do antígeno comercial foi determinado pelo método de HARTREE (1972). Realizou-se o dot blotting segundo MARTINS et al. (2005), para verificar a reatividade dos antígenos APTX e o comercial, incubados com soros-controle positivos anti- $R$. equi e negativos.

A titulação de anticorpos anti- $R$. equi foi realizada nos grupos experimentais nos momentos já referidos pelo teste indireto ELISA, conforme a técnica preconizada por TAKAI et al. $(1985,1986)$, modificada por MARTINS et al. (2005).

As concentrações dos antígenos e dos soroscontrole positivo e negativo foram preconizados por MARTINS et al. (2005), cujos resultados da titulação em bloco determinaram a concentração ótima dos antígenos em $2,0 \mu \mathrm{g} / \mathrm{mL}$ para o ELISA IgG, em tampão carbonato/bicarbonato. Adotou-se diluição única de 1:200 para os soros de referência positivo e negativo e soros-teste no ELISA IgG. O conjugado ${ }^{3}$ usado, constituído de IgG de coelho anti-IgG de equino acoplada à fosfatase alcalina, foi diluído a 1:15000 em PBS-Tween 80 acrescido de $6 \%$ de leite em pó desnatado. ${ }^{4}$
Para obtenção dos soros de referência positivos, utilizou-se o soro positivo-controle presente no kit de diagnóstico para imunodifusão ${ }^{1}$ e soros de equinos ( $\mathrm{n}=16$ ), colhidos após a segunda vacinação para $R$. equi. As amostras de soros de referência negativos foram obtidas dos potros recém-nascidos, antes da ingestão do colostro $(\mathrm{n}=16)$, conforme descrito por MARTINS et al. (2005).

Agruparam-se os valores de absorbância média dos soros em níveis de ELISA (NE), os quais variaram de 0 (zero) a 9 (nove). O limite máximo do nível zero foi determinado pela média dos valores de absorbância de soros de animais não imunes ao $R$. equi, acrescidos de dois desvios-padrões. A partir desse limite, definiram-se os intervalos entre os outros níveis de ELISA por acréscimo de $35 \%$, conforme preconizado por MACHADO et al. (1997), para sistema Babesia bovis, e MARTINS et al. (2005), para $R$. equi.

Os dados foram avaliados pela análise de variância (ANOVA), com o procedimento Modelo Linear Geral (GLM) do programa computacional Statistical Analysis Systems (SAS), segundo o delineamento em parcelas subdivididas no tempo, tendo como parcela a combinação de dois antígenos e na subparcela os momentos de colheita de amostras. Utilizou-se o teste de Tukey para as comparações múltiplas das médias dos grupos nos diferentes momentos, estabelecendo-se o nível de significância igual a $\mathrm{p} \leq 0,05$.

\section{RESULTADOS}

Os potros não demonstraram alterações nos parâmetros avaliados até 150 dias de idade.

Os antígenos APTX e comercial não reagiram com os soros dos grupos-controle negativos na diluição de 1:100, no entanto reagiram fortemente com os soros do grupo-controle positivos testados.

Após a aplicação do teste indireto ELISA a dezesseis soros negativos, obteve-se, para estes, uma média de $\mathrm{A} / \mathrm{P}$ (amostra em relação ao positivo) de 0,177 $\pm 0,004$ para o antígeno $(\mathrm{Ag})$ APTX e 0,164 $\pm 0,0031$ para o Ag comercial. Atribuiu-se como negativos os níveis de ELISA entre $0,1,2$ e 3 (faixas de $\mathrm{A} / \mathrm{P}$ de 0,000 - 0,450 para o Ag APTX; e 0,000 - 0,414 para o $\mathrm{Ag}$ comercial) e positivo o nível $\geq 4$ (faixas de $\mathrm{A} / \mathrm{P}$ de 0,451 - 2,716 para o Ag APTX e 0,415 - 2,500 para o Ag comercial). 
Não houve diferenças na resposta imune humoral entre as éguas das raças BH e Bretão. Foram registradas diferenças significativas tanto para o momento de colheita $(\mathrm{p}<0,01)$ como para o tipo de antígeno empregado $(\mathrm{p}<0,01)$. Os títulos de anticorpos anti- $R$. equi, classificados em níveis de ELISA, detectados 45 dias antes do parto e antes da administração da primeira dose da vacina, foram os mais baixos registrados no grupo de éguas vacinadas $(\mathrm{NE}<2)$. Aumentos significativos $(\mathrm{p}<0,01)$ foram registrados quinze dias antes do parto ( $\mathrm{NE} \geq 4)$, momento da segunda vacinação. As concentrações de anticorpos elevaram-se discretamente após aplicação da segunda dose da vacina, atingindo a titulação máxima no momento do parto apenas para o $\mathrm{BH}(\mathrm{NE} \geq 4)$ e ocorrendo um declínio nos valores observados sessenta dias após o parto $(\mathrm{NE}<4)$, mantendo-se, então, constante até 150 dias deste $(3<\mathrm{NE}<4)$. $\mathrm{O}$ antígeno comercial reagiu com maior afinidade $\mathrm{e}$ avidez com os anticorpos induzidos pelo antígeno vacinal ou natural do indivíduo, detectando títulos maiores $(\mathrm{p}<0,01)$ que o APTX. Os grupos vacinados apresentaram títulos de anticorpos significativamente maiores que o grupo-controle, no qual não se observou alteração significativa dos títulos (Figura 1A).

Não se notou diferença na resposta humoral entre potros das raças BH e Bretão. Foram registradas diferenças significativas tanto para o momento de colheita $(\mathrm{p}<0,01)$ como para o tipo de antígeno empregado $(p<0,01)$. Houve diferenças significativas nos títulos de anticorpos entre os potros filhos de éguas vacinadas e os filhos de éguas-controle $(p<0,01)$. Neste último, a alteração dos títulos não foi considerada significativa. Em relação aos títulos de anticorpos dos potros filhos de éguas vacinadas, no momento do nascimento apresentaram os menores títulos de anticorpos $(\mathrm{NE}<1)$, elevando-se significativamente $(\mathrm{p}<0,01)$ após a ingestão do colostro $(\mathrm{NE} \geq 4)$. Diminuição dos títulos de anticorpos foi observada sessenta dias após o nascimento $(2<\mathrm{NE}<3)$, mantendo-se estável até 150 dias (NE $\geq 2)$ (Figura 1B).
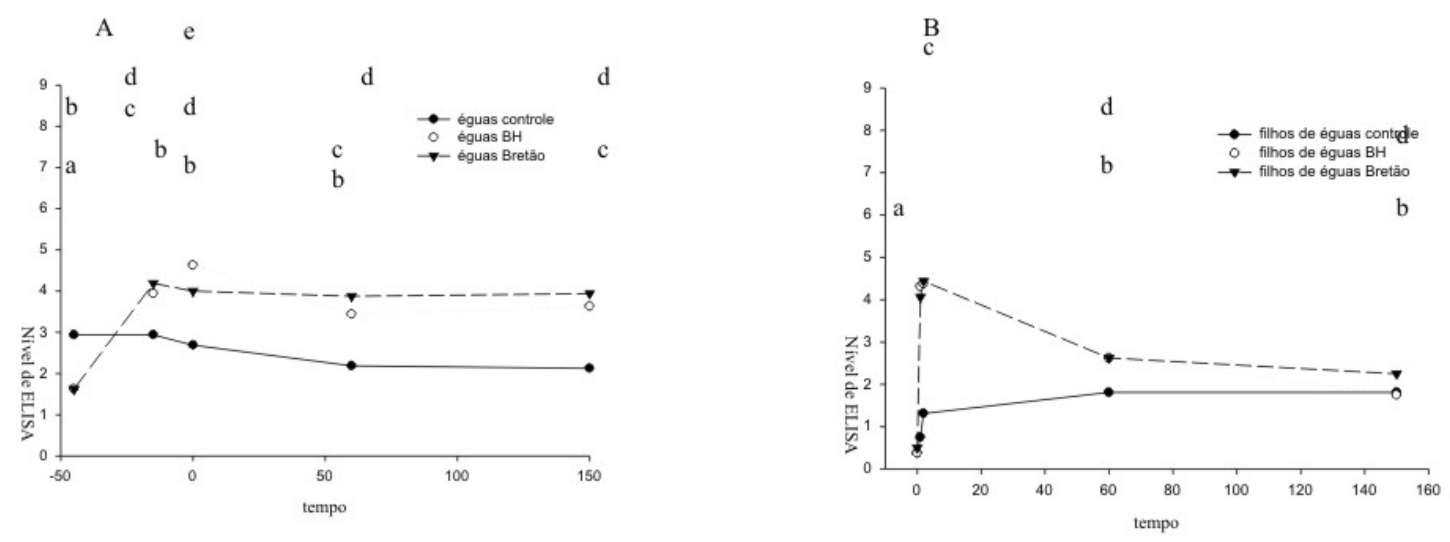

FIGURA 1. Níveis de anticorpos anti-R.equi em soros de éguas-controle e vacinadas (BH e Bretão) (A) e soros dos potros filhos de éguas-controle, $\mathrm{BH}$ e Bretão (B), em diferentes momentos do período experimental.

\section{DISCUSSÃO}

Houve diminuição do número de casos de infecção por R. equi, diagnosticados em equinos na propriedade sob estudo, com a introdução de vacina comercial em éguas prenhes. Entretanto, não havia comprovação científica sobre a importância dessa vacinação na transferência de anticorpos específicos para os potros.
Os resultados deste estudo, em relação à imunização de éguas com a vacina comercial, mostraram elevação sérica significativa de anticorpos anti-R. equi após a sua administração, mantendo os títulos altos até o momento do parto e apresentando um ligeiro declínio aos sessenta dias pós-parto. No entanto, nesse último período os títulos ainda foram considerados elevados $(\mathrm{NE} \geq 4)$, quando testados para os dois antígenos. 
TAKAI et al. (1985) e CUTERI et al. (2003) consideraram positivos, para a presença de anticorpos contra $R$. equi, os valores de densidade óptica (DO) $>0.3$ obtidos a partir da leitura da reação do teste ELISA.

Algumas éguas pertencentes ao grupo-controle apresentaram títulos de anticorpos elevados antes da vacinação. Tal fato pode ser justificado pela grande variação nos títulos de anticorpos encontrada em equinos de diversas idades, expostos naturalmente ao $R$. equi (ELLENBERGER et al., 1984, TAKAI et al., 1987).

A vacinação das éguas foi importante no aumento do título de anticorpos anti- $R$. equi, em potros após a ingestão de colostro, o que não ocorreu nos animais que ingeriram colostro de éguas não vacinadas. Esses achados corroboram os de ELLENBERGER et al. (1984) e MADIGAN et al. (1989), os quais observaram transferência de anticorpos através do colostro de éguas imunizadas contra o $R$. equi para os potros. HIETALA et al. (1985) relataram que os anticorpos específicos adquiridos com a ingestão de colostro mantiveram títulos altos até os potros completarem dois meses de idade, quando entraram em declínio gradativo, e os anticorpos autógenos aumentaram após 45 e sessenta dias de idade, corroborando com os achados deste estudo. Mesmo ocorrendo diminuição dos títulos de anticorpos aos sessenta dias, as concentrações ainda foram consideradas elevadas.

Embora a vacinação das éguas no último trimestre de gestação tenha conferido altos títulos de anticorpos anti- $R$. equi aos potros e estes tenham permanecido saudáveis no decorrer deste estudo, não se pode afirmar que houve proteção adequada, já que os potros não foram desafiados contra o agente patogênico. Entretanto, acredita-se que a vacinação das éguas pode ser considerada como uma ferramenta importante na luta contra tal enfermidade.

BECÚ et al. (1997) observaram um efeito significativo da vacinação de éguas prenhas com a vacina comercial na prevenção contra a pneumonia pelo $R$. equi. Na Argentina e em outros países sul-americanos, a enfermidade é controlada com a vacinação das éguas antes do parto, e em alguns casos com a administração do plasma hiperimune nos potros, sendo esta efetuada somente quando são detectados títulos baixos de anticorpos 48 horas após o nascimento (BECÚ, 1999). Embora a imunidade humoral esteja envolvida na proteção precoce de potros jovens (ELLENBERGER et al., 1984; TAKAI, 1985), a imunidade mediada por células é reconhecida por desempenhar um importante papel na eliminação da infecção por $R$. equi em desafios experimentais em camundongos e sem a qual a capacidade de combate a esse agente fica comprometida (BREATHNACH et al., 2006). Os potros possuem capacidade de resposta celular do tipo Th1, caracterizada pela produção de INF- $\gamma$, entretanto o limiar de estimulação dessa resposta não é elevado (BREATHNACH et al., 2006). HOOPER-McGREVY et al. (2005) estudaram a resposta imune em potros imunizados oralmente com preparado purificado de proteínas associadas à virulência (Vaps) e observaram que os animais imunizados não desenvolveram a doença após a inoculação da bactéria.

Há possibilidade de a imunodeficiência em neonatos estar associada à baixa produção de citocinas Th-1 (UPHAM et al., 2002). Segundo MARODI (2002), os macrófagos podem apresentar hiporresponsividade ao INF- $\gamma$. Entretanto, considera-se que as células $\mathrm{T}$ neonatais possam produzir INF- $\gamma$ sob condições de estimulação apropriadas (ADKINS et al., 2004). Trabalhos recentes sugerem que os neonatos são Th-1 imunocompetentes, mas possuem alto limiar para ativação dessas respostas (BREATHNACH et al., 2006).

$\mathrm{O}$ teste com o antígeno comercial demonstrou melhor resultado que o antígeno APTX. A diferença na magnitude das respostas entre os antígenos testados deve-se possivelmente à diferença na caracterização antigênica presente em cada um. O antígeno APTX consiste em uma preparação semipurificada da proteína VapA, enquanto o antígeno comercial possivelmente possui maior número de determinantes antigênicos, além da VapA. No entanto, a cinética da resposta imune humoral nos animais estudados foi similar em relação aos dois antígenos testados, apresentando o mesmo ponto de corte na escala de determinação do nível de ELISA (NE $\geq 4)$.

As éguas Bretãs têm sido utilizadas por criadores de diversas raças como receptoras de embrião e para amamentar os potros, por apresentarem útero maior e fornecerem em média 24 litros de leite por dia. Já as raças de sela fornecem quatorze litros e apresentam excelente habilidade materna (REVISTA DA TERRA, 2009). Embora éguas da raça Bretão produzam maior quantidade de leite que as outras raças, não foram 
observadas diferenças quanto à concentração de anticorpos séricos anti- $R$. equi entre éguas $\mathrm{BH}$ e Bretãs $\mathrm{e}$ nem entre seus produtos.

\section{CONCLUSÕES}

A vacina Rhodovac ${ }^{\circledR}$ induziu a formação de anticorpos às éguas imunizadas. Houve transferência de anticorpos anti-R. equi através do colostro para os potros. Os títulos de anticorpos anti- $R$. equi foram maiores nos potros que mamaram colostro oriundo de éguas vacinadas. Não houve efeito da raça quanto à produção de anticorpos anti- $R$. equi. $\mathrm{O}$ antígeno comercial detectou títulos de anticorpos maiores que o antígeno APTX. Novas pesquisas devem ser realizadas no intuito de esclarecer os fatores envolvidos no mecanismo da resposta imune à infecção por $R$. equi e contribuir para a formulação de medidas preventivas eficazes a serem adotadas.

\section{FONTES DE AQUISIÇÃO}

${ }^{1}$ Clinica Equina SRL, Capitán Sarmiento, Argentina

${ }^{2}$ Nitrocellulose membrane for use in ECL Westernblotting - Amersham Pharmacia Biotech

${ }^{3}$ Conjugate Anti-Horse - Sigma A 6063

${ }^{4}$ Molico - Nestlé.

\section{AGRADECIMENTOS}

À Fundação de Amparo à Pesquisa do Estado de São Paulo (FAPESP), pelo financiamento da presente pesquisa (Processo no 01/10120-6), à Fazenda de Criação São Geraldo e ao Pólo Regional de Desenvolvimento Tecnológico de Agronegócios da Alta Mogiana, pela cessão dos animais.

\section{REFERÊNCIAS}

ADKINS, B.; LECLERC, C.; MARSHALL-CLARKE, S. Neonatal adaptive immunity comes of age. Nature Review Immunology, v. 4, p. 553-564, 2004.

BECÚ, T.; POLLEDO, G.; GASKIN, J. M. Immunoprophylaxis of Rhodococcus equi pneumonia in foals. Veterinary Microbiology, v. 6, p. 193-204, 1997.

BECÚ, T. Shinji Takai estuda o Rhodococcus na Argentina. Saúde Equina, v. 2, n. 13, p. 16-17, 1999.
BREATHNACH, C. C; STURGILL-WRIGHT, T.; STILNER, J. L.; ADAMS, A. A.; LUNN, D. P.; HOROHOV, D. W. Foals are interferon gamma-deficient at birth. Veterinary Immunology and immunopathology, v. 112, p. 199-209, 2006.

CUTERI, V.; TAKAI, S.; MOSCATIC, L.; BATTISTACCIC, L.; PIERAMATID, C.; VALENTE, C. A serological survey of Rhodococcus equi infection in foals in central Italy: comparation of two antigens using an ELISA test. Comparative Immunology, Microbiology and Infectious Diseases, v. 26, p. 17-23, 2003.

ELLENBERGER, M. A.; KAEBERLE, M. L.; ROTH, J. A. Equine humoral immune response to Rhodococcus (Corynebacterium) equi. American Journal Veterinary Research, v. 45, n. 11, p. 2428-2430, 1984.

HARTREE, E. F. Determination of protein: a modification of the Lowry method that gives a linear photometric response. Analysis Biochemistery, v. 48, p. 422-427, 1972.

HIETALA, S. K.; ARDANS, A. A.; SANSOME, A. Detection of Corynebacterium equi specific antibody in horses by enzymelinked immunosorbent assay. American Journal of Veterinary Research, v. 46, n. 1, p. 13-15, 1985.

HOOPER-McGREVY, K. E.; WILKIE, B. N.; PRESCOTT, J. F. Virulence-associated protein-specific serum immunoglobulin G-isotype expression in young foals protected against Rhodococcus equi pneumonia by oral immunization with virulent $R$. equi. Vaccine, v. 23, n. 50, p. 5760-5767, 2005.

MACHADO, R. Z.; MONTASSIER, H. J.; PINTO, A. A.; LEMOS, E. G.; MACHADO, M. R. F.; VALADÃO, I. F. F.; BARCI, L. G.; MALHEIROS, E. B. An enzyme-linked immunosorbent assay (ELISA) for detection of antibodies againt Babesia bovis in cattle. Veterinary Parasitology, v. 71, p. 17-26, 1997.

MADIGAN, J. E.; HIETALA, S.; MULLER, N. Acquisition of passive immunity against $R$. equi in foal by administration of hyperimmune plasma. American Association of Equine Practioners, v. 35, Lexington. Proceedings... p. 521-522, 1989.

MARODI, L. Deficient interferon-gamma receptor-mediated signaling in neonatal macrophages. Acta Paediatrica, Suppl. 91, p. $117-119,2002$.

MARTINS, C. B.; BONESSO, M. A.; LIMA, M. M.; FERRAZ, L. C.; LACERDA NETO, J. C.; MACHADO, R. Z. Ensaio imunoenzimático indireto (ELISA) para detecção de anticorpos anti-Rhodococcus equi em potros. Ciência Rural, v. 35, p. 618624, 2005.

PRESCOTT, J. F; NICHOLSON, V. M.; PATTERSON, M. C.; ZANDONA MELEIRO, M. C.; CATERINO, A. A.; YAGER, J. A.; 
HOLMES, M. A. Use of Rhodococcus equi virulence-associated protein for immunization of foals against pneumonia. American Journal Veterinary Research, v. 58, p. 356-359, 1997.

REVISTA DA TERRA. Cavalo Bretão. Disponível em: www. portalsaofrancisco.com.br. Acesso em: 22 de jun. 2009.

TAKAI, S.; KAWASU, S.; TSUBAKI, S. Enzyme-linked immunosorbent assay for diagnosis of Corynebacterium (Rhodococcus) equi infection in foal. American Journal of Veterinary Research, v. 46, n. 10, p. 2166-2170, 1985.

TAKAI, S.; NARITA, K.; ANDO, K.; TSUBAKI, S. Ecology of Rhodococcus (Corynebacterium) equi soil on a horse-breeding farm. Veterinary Microbiology, v. 12, p. 169-177, 1986.
TAKAI, S.; FUJIMORI, T.; KATSUZAKI, K; TSUBAKI, S. Ecology of Rhodococcus equi in horses and their environment on horse-breeding farm. Veterinary Microbiology, v. 14, p. 233239, 1997.

UPHAM, J. W.; LEE, P. T.; HOLT, B. J.; HEATON, T.; PRESCOTT, S. L.; SHARP, M. J.; SLY, P. D.; HOLT, P. G. Development of interleukin-12-producing capacity throughout childhood. Infection and Immunity, v. 70, p. 6583-6588, 2002.

Protocolado em: 24 abr. 2009. Aceito em: 24 ago. 2009. 